\title{
The Osteogenic Differentiation of Mice Bone Marrow Mesenchymal Stem Cells with Fisetin Phytoestrogen
}

\author{
Elahe Vadaye Kheiry ${ }^{1}$, Kazem Parivar $^{2}$, Javad Baharara ${ }^{3} \&$ Alireza Iranbakhsh ${ }^{4}$ \\ ${ }^{1}$ Department of Biology, Science and Research Branch, Islamic Azad University, Tehran, Iran \\ ${ }^{2}$ Department of Biology, Science and Research Branch, Islamic Azad University, Tehran, Iran \\ ${ }^{3}$ Department of Biology, Research Center for Applied Biology, Mashhad Branch, Islamic Azad University, \\ Mashhad, Iran \\ ${ }^{4}$ Department of Biology, Science and Research Branch, Islamic Azad University, Tehran, Iran \\ Correspondence: Kazem Parivar. Department of Biology, Science and Research Branch, Islamic Azad University, \\ Tehran, Iran. Email: kazem_parivar@yahoo.com
}

Received: July 17, 2017

doi:10.5539/jmbr.v7n1p162
Accepted: August 8, $2017 \quad$ Online Published: November 10, 2017

URL: https://doi.org/10.5539/jmbr.v7n1p162

\begin{abstract}
Objective(s): The aim of this study was to evaluate the effects of fisetin to promote osteogenic differentiation in mice bone marrow mesenchymal stem cells (BMSCs).

Materials and Methods: In this study cytotoxicity and viability of fisetin was measured by MTT assay. The differentiation effects of fisetin on BMSCs into osteoblast was assessed with alkaline phosphatase (ALP) activity measurement. Alizarin red staining and Real time PCR for osteoblast specific marker, Osteocalcin (OCN), Osteopontin (OPN), Runt-related transcription factor 2 (RUNX2), ERK and MAPK were investigated

Results: The results showed that fisetin does not have toxicity effect on BMSCs and it causes cell proliferation; hence 200,400 and $800 \mu \mathrm{g} / \mathrm{ml}$ of fisetin was selected for the assessment of differentiation progress. Alizarin red staining (ARS) showed that fisetin promotes osteogenic differentiation on BMSCs at 21st day; dependently also higher alkaline phosphates activity was observed in the treatment groups of 10 days culture, compared to the control groups. The evaluation of Real time -PCR result evaluated showed that OCN OPN, RUNX2,ERK and MAPK genes expressions were increased.
\end{abstract}

Conclusion: The results of this method, showed that differentiation in bone marrow stem cells took place through p38 MAPK, and ERK1 gene activation.

Keywords: Osteogenesis, Mesenchymal stem cell, Fisetin, OCN, OPN

\section{Introduction}

Osteoporosis is a kind of skeletal disease, it is characterized by a high risk of bone fragility and fracture, low bone mineral density and bone pain. Postmenopausal women are a high risk group for osteoporosis due to the decreased secretion of estradiol hormones in menopaused women (Xu et al., 2016). In petition with osteoporosis, bone resorption was increased and bone formation was decreased (Sealy-Jefferson et al., 2016). For the prevention or treatment of osteoporosis, some drugs are used to inhibit bone resorption and increase bone formation (Kulpa et al., 2012). Hormone replacement therapy (HRT) is the way for the treatment of osteoporosis and Estrogen, known as a tissue regulator such as bone (Nongmaithem et al., 2016) and plays a fundamental role in skeletal growth and bone homeostasis in both men and women (Niada et al., 2016). It controls the activity of bone-forming osteoblasts and bone-resorbing osteoclasts, the physiological effects of estrogen are mediated by estrogen receptors (Wang et al., 2016). Estrogens have some receptors in bone and other tissues like brain, cardiovascular system, skin, liver, adipose tissue, the immune system, and others. Estrogen receptors are divided into two types: estrogen receptor $\alpha$ (ER- $\alpha)$ and estrogen receptor $\beta$ (ER- $\beta$ ), the effects of estrogens are mediated predominantly by the action of estrogen receptor alpha (Jia et al., 2015).But some studies have reported that the application of estrogen has bad effects such as breast cancer (Chlebowski et al., 2015).Due to the results, researcher have focused on finding some natural compounds with estrogen, like anabolic effect (Jia et al., 2015).Some supplements capable of estrogen receptor activity, such as phytoestrogen (Nanashima et al., 2015). Phytoestrogens are selective estrogen receptor 
modulators with the potentiality to be used in HRT to relieve peri/postmenopausal symptoms, Phytoestrogens are plant-derived compounds found in a wide variety of foods (Schilling et al., 2015). They can bind the estrogen receptor and activate it; their effects are similar to those of estrogen (Jia et al., 2015). They are capable of being replaced by estrogens and may be implicated in lowering the risk of osteoporosis, heart disease, breast cancer, and menopausal symptoms (Chlebowski et al., 2015). Many of researches reported that phytoestrogens can decrease bone disease, for example Michelin reports that Ginestein (known phytoestrogen) is beneficial to promote bone health (michelin et al., 2015). Some studies focused on resveratrol's beneficial effects on bone (Gambini et al., 2015). Fisetin (3, 7, 3', 4'-tetrahydroxyflavone) is dietary flavonoid and one type of phytoestrogens (Lall et al., 2016). It has been found in some fruits and vegetables, such as strawberry, apple, persimmon, grape, mango, union, and cucumber (pal et al., 2015). Several biological effects of fisetin, including cardio protective, neuroprotective, anti-inflammatory, anticancer, immunomodulatory, and anti oxidative, have been reported (Lall et al., 2016). With regard to phytoestrogen's benefits on bone regeneration, the aim of this study was to investigate osteogenic differentiation of Fisetin on bone marrow mesenchymal stem cells from mice.

\section{Material and Method}

\subsection{Reagents}

Dubelco's modified essential medium (DMEM), penicillin-streptomycin, trypan blue, and fisetin were all purchased from Sigma-Aldrich. The high pure RNA Isolation kit was purchased from Denazist (Iran), and cDNA synthesized kit (Fermantas). For PCR reaction, the Parstoos kit was ontained from Iran. primer, from Bioneer (Korea. Alkaline phosphatase activity measurement kit was purchased from Parsazmoon industry (Iran). All the solutions were prepared, using double distilled water. Other chemicals were of analytical grades and used.

\subsection{Isolation and Expansion of BMSCS}

Bone marrow cells were harvested by flushing the femurs bone marrow of 6-8 weeks old mice with DMEM, then the cells were centrifuged, and suspended in DMEM with $10 \%$ FBS. Cells were incubated at $37^{\circ} \mathrm{C}$ in $5 \%$ humidified $\mathrm{CO} 2$ for $24 \mathrm{~h}$ until the medium was replaced to remove the non-adherent cells. When cells reached $90 \%$ confluency, they were trypsinized, with $0.25 \%$ trypsin for $5 \mathrm{~min}$ at $37^{\circ} \mathrm{C}$. After centrifugation, cells were resuspended and used for other analysis.

\subsection{Stem Cell Identification}

To prove that the utilized cells are stem cells, flow cytometry method againsst stem cell specific marker was conducted. After cells were separated from the bottom of the flask, they were centrifuged. The primary antibody CD44, CD31 and CD45 was conjugated and isothiocyanate (FITC) was added to the cells. They were washed with PBS and were fixed with formalin. Then it was analyzed by flow cytometer.

\subsection{Determination of Cell Viability}

In order to count live and dead cells, at 24-hour intervals, the cells were first trypsinized and carefully separated from the plate completely. Then, for each plate cavity, $100 \mu \mathrm{l}$ of cell suspension was mixed with $\mu 1100$ Trypanobul (sigma) solution then), the number of colored cells (dead cells) and uncolored cells (living cells) determined by the use of a hemocytometer lam (neobar lam). Viability percentage was calculate using follow Equation:

Viability percentage $=($ survival of cells in the presence of the doses of fesitin/total cells $\times 100)$

\subsection{Cell Treatment for Induced Differentiation}

Cells were cultured in 12-well plates after $24 \mathrm{~h}$, the cells were treated with 200,400 and $800 \mu \mathrm{g} / \mathrm{ml}$ fisetin. This treatment was continued for 10 or 21 days, each four day, the medium was replaced and treated again with fisetin. Finally, the differentiations of mesenchymal stem cells into osteoblast were evaluated by ALP activity on 10th and alizarin red and Real time-PCR at 21 th days.

\subsection{ALP Activity}

BMSCs were cultured in 12 well plate dishes for 24 hours, as described previously, and then they were treated with 200,400 and $800 \mu \mathrm{g} / \mathrm{ml}$ fisetin for 10 days. To determine the level of alkaline phosphatase activity, total cell protein was extracted using $200 \mu \mathrm{l} \mathrm{NP} 40$ buffer (Sigma, uk). The lysate was then centrifuged at $14,000 \times \mathrm{g}$ at $4{ }^{\circ} \mathrm{C}$ for 15 min. Supernatant was collected and ALP activity was measured with ALP assay kit (Parsazmoon, Iran) using p-nitrophenyl phosphate (p-NPP), as substrate and alkaline phosphatase were provided in the kit as standard.

\subsection{Alizarin Red Staining}

BMSCs were cultured in 12 well plate dishes and were treated with 200,400 and $800 \mu \mathrm{g} / \mathrm{ml}$ week for 21 days, cells were washed with PBS and fixed by $4 \%$ paraformaldehyde for $10 \mathrm{~min}$; and then enough Alizarin Red staining 
solution was added to cover the cellular monolayer. They incubated at room temperature in the dark environment. The stained solution was removed after $45 \mathrm{~min}$. Each well was washed and observed with invert microscopy. Highresolution images were then captured with a digital camera.

\subsection{RNA Extraction, cDNA Synthesis and Real Time PCR}

Based on the results of ALP activity assay and Alizarin red staining, BMSCs $(30 \times 106)$ were treated with 800 $\mu \mathrm{g} / \mathrm{ml}$ fisetin for 21 days. After this duration, RNA was extracted, according to manufacturer instructions. The mRNA was reverse transcribed to cDNA, using cDNA synthesis kit, according to manufacturer instructions. The expression of OCN, OPN, Runx-2, MAPK and ERK and genes was analyzed using specific primer and Syber green dye.

Table 1. Sequencing of used primers

\begin{tabular}{lll}
\hline Gene & Forward & Reverse \\
\hline GAPDH & 5' TGAAGGTCGGTGTGAACGGATTTGGC 3' & 5' CATGTAGGCCATGAGGTCCACCAC 3' \\
MAPK & 5' TTTGCTTCAGGGTTTCATCCA 3' & 5' CTCCATGTTACTGTCCAGTTCGT 3' \\
ERK-1 & 5' CATGTGTGTGGAGAGCGTCAAC 3' & 5' CAGATAGGCACCCAGGGTGAT 3' \\
OCN & 5' GTG CAG AGT CCA GCA AAG GT 3' & 5' CGA TAG GCC TCC TGA AAG C 3' \\
OPN & 5' ACA GCC AGG ACT CCA TTG AC 3' & 5' ACA CTA TCA CCT CGG CCA TC 3' \\
Runx2 & 5'CTC ACT ACC ACA CCT ACC TG 3' & 5' TCA ATA TGG TCG CCA AAC AGA TTC 3' \\
\hline
\end{tabular}

\subsection{Statistical Analysis}

The statistical evaluation of the data was performed using one-way analysis of variance (ANOVA), a Tukey test used for multiple comparisons as a posttest with the help of SPSS software. The results were shown as Mean \pm $\mathrm{SD}$, and $\mathrm{P}<0.05$ was calculated as the minimum level of significance.

\section{Result}

\subsection{The Results of the Expression of Surface Marker Analysis by Flow Cytometric}

Flow cytometric results confirmed the presence of mesenchymal stem cells. The flow cytometric analysis of isolated BMSCs for mesenchymal stem cell markers (CD44), hematopoietic marker (CD45), endothelial marker (CD31), were positive for CD44, but they were negative for CD31 and CD45.
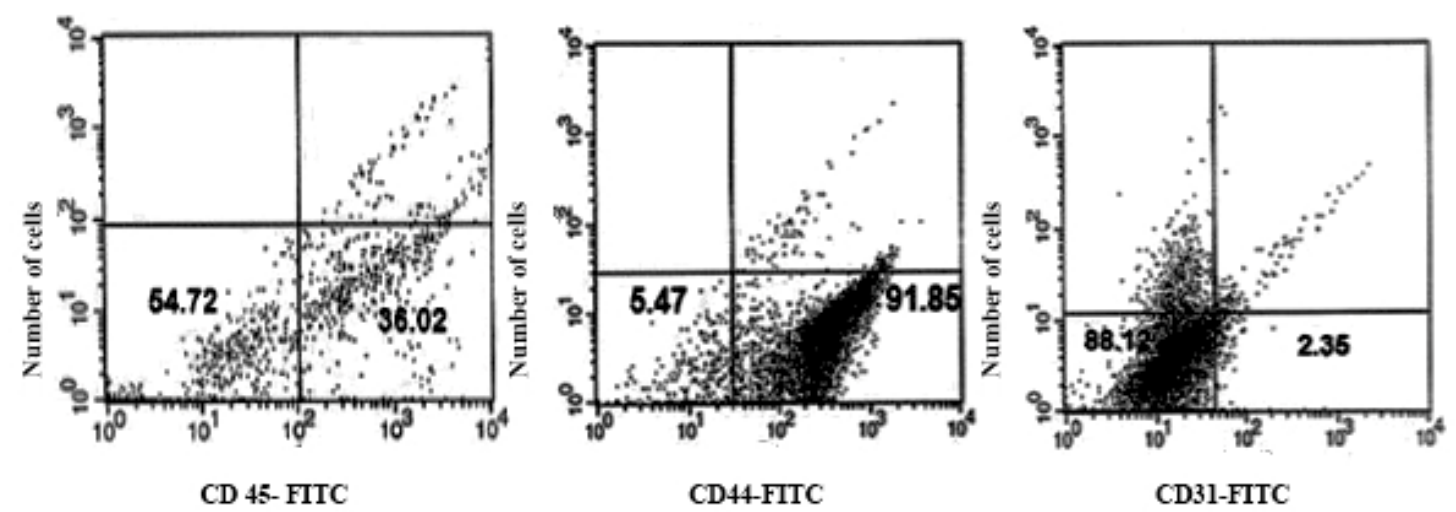

Figure 1. Flow cytometric results confirmed the presence of mesenchymal stem cells. The results showed the presence of mesenchymal stem cells

\subsection{Results Counting the Number of Cells}

Cytotoxicity results showed the fact that cell viability in the treated cell was increased in a dose dependent manner, but in cells treated with 50 and $200 \mu \mathrm{g} / \mathrm{ml}$ of fisetin, cells viability wasn't significant and the higher viability percentage was observed in the cells treated with higher dose of festin $(800 \mu \mathrm{g} / \mathrm{ml})$ (Figure 2). 


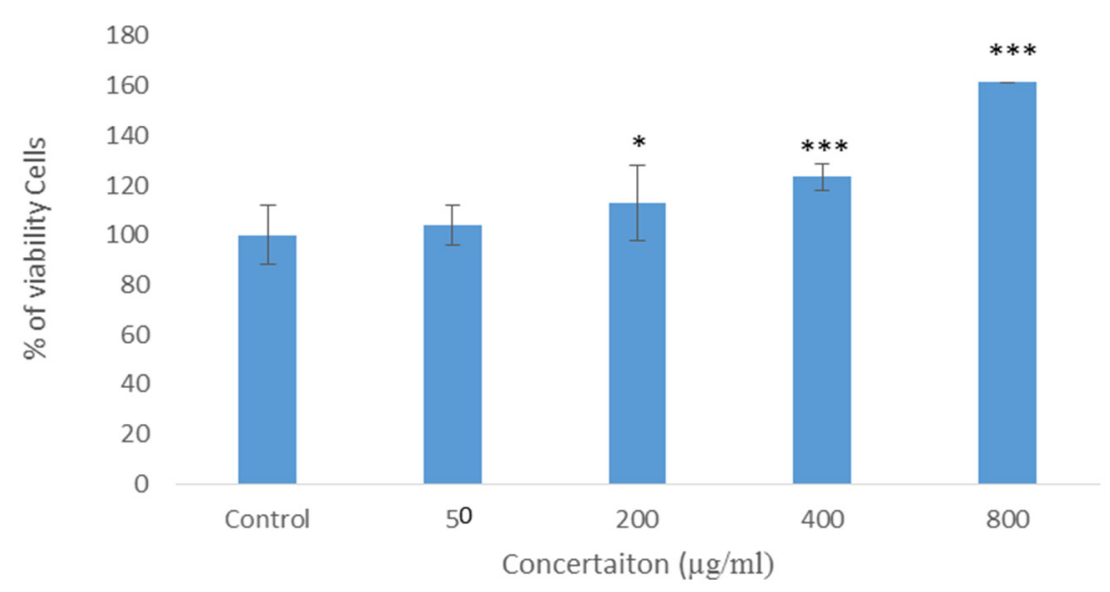

Figure 2. BMSCs were treated with varying concentrations of Fisetin for $24 \mathrm{~h}$, and cell viability was measured, using trypan blue. The results Indicated that the viability of Cells increased with high doses, (Mean \pm S.E

،*P<0.05, Mean \pm S.E ،*** $\mathrm{P}<0.001)$

\subsection{The Results of ALP Activity}

The results of ALP activity assay indicated that in treated cells ALP activity was increased dose dependently, compared to the control groups, however, the higher ALP activity was observed in $800 \mu \mathrm{g} / \mathrm{ml}$ of fisetin (Figure 3).

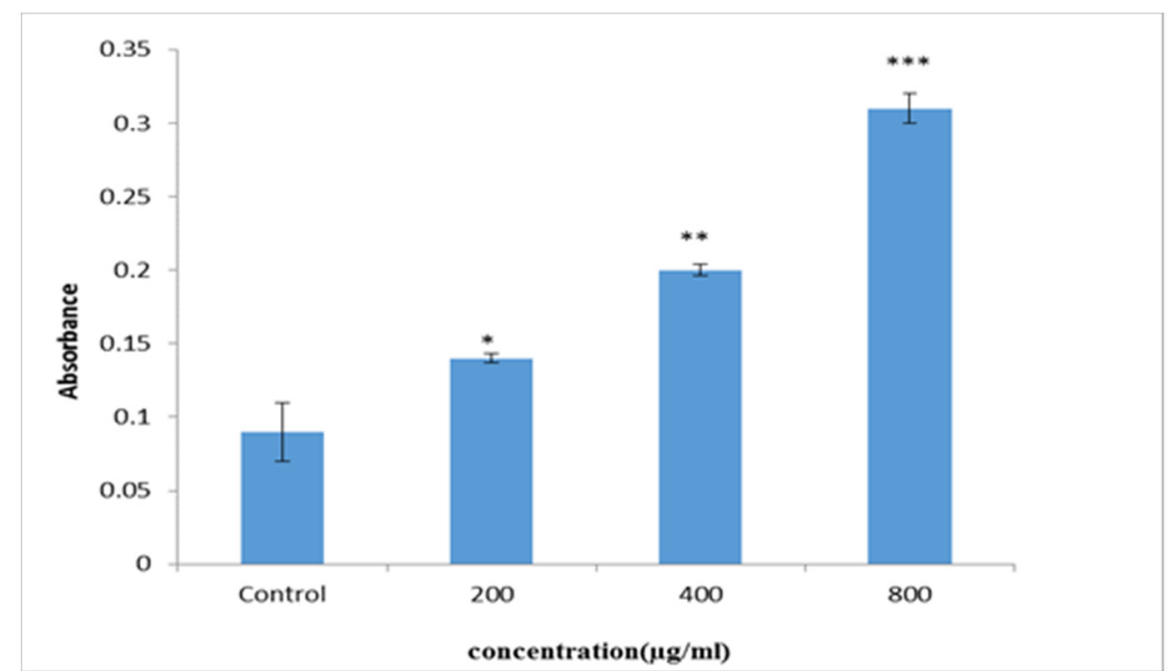

Figure 3. The comparison of alkaline phosphatase activity in treated cells and control groups. The diagram shows that the optical absorption of cells treated with fisetin $800 \mu \mathrm{g} / \mathrm{ml}$, were significantly increased, compared with the control groups (Ments \pm S.E, ${ }^{* *} \mathrm{P}<0.01$, Mean \pm S.E ،*** $\mathrm{P}<0.001$ )

\subsection{Alizarin Red Staining}

Alizarin red staining was performed after 21 days in those cells that were treated with 200,400 and $800 \mu \mathrm{g} / \mathrm{ml}$ of fisetin treatment. The results of alizarin red staining showed that fisetin is able to induce the differentiation of BMSCs into osteoblasts concentration dependently. In higher concentration, more calcium deposition was observed. BMSCs that were not treated with fisetin were considered as control group (Figure 4). 

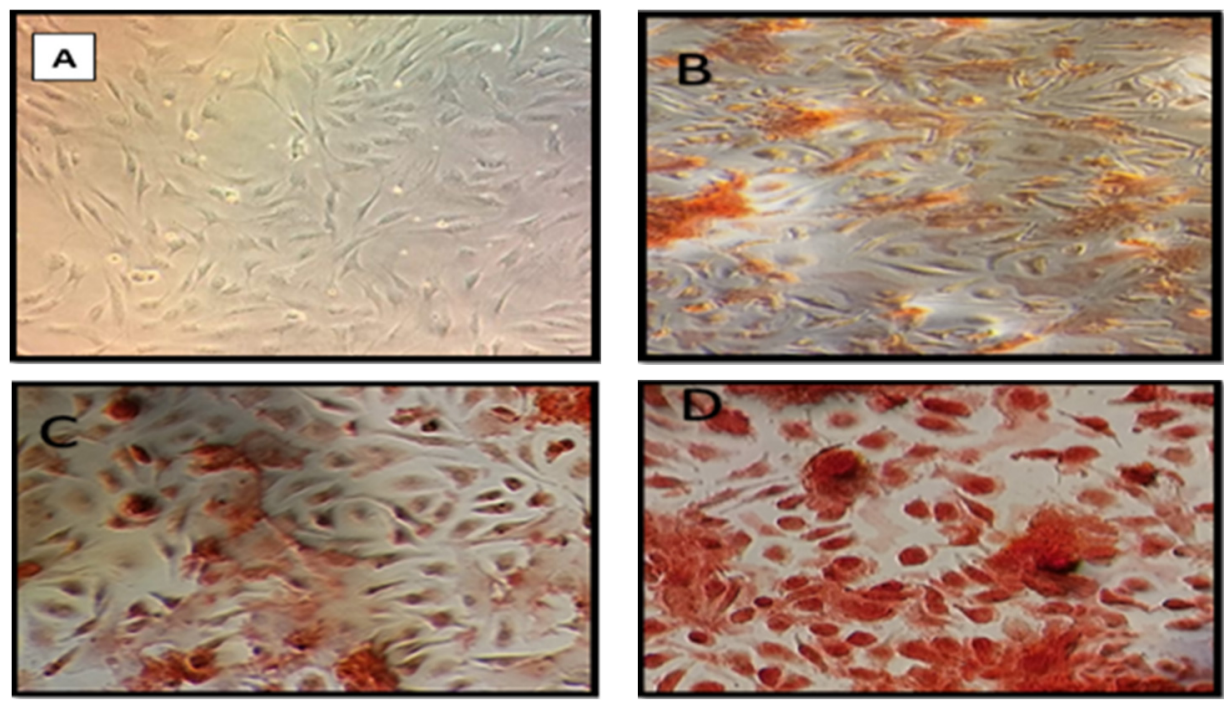

Figure 4. The results of Alizarin red staining: MSCs were treated with (B) $200 \mu \mathrm{g} / \mathrm{ml}$, (C) $400 \mu \mathrm{g} / \mathrm{ml}$ and

$800 \mu \mathrm{g} / \mathrm{ml}$ Fisetin for 21 days . Result showed to visualize calcium deposition in the extracellular matrix camprition control groups. Magnification $10 \times 10$

\subsection{Real Time PCR}

The Significant upregulation of OPN, OCN and RUNX2 expression takes place in those groups that treated with $800 \mu \mathrm{g} / \mathrm{ml}$ of fisetin. OPN, OCN expression is associated with osteoblastic differentiation. In the current study, the undergoing mechanism that leads to osteoblast differentiation was investigated through analyzed ERK1 and MAPK signaling pathways. The results showed that festin activates ERK1 and MAPK pathways. Hence, the commitment of BMSCs to osteogenic linage takes plate through ERK1-MAPK pathway (Figure 5).

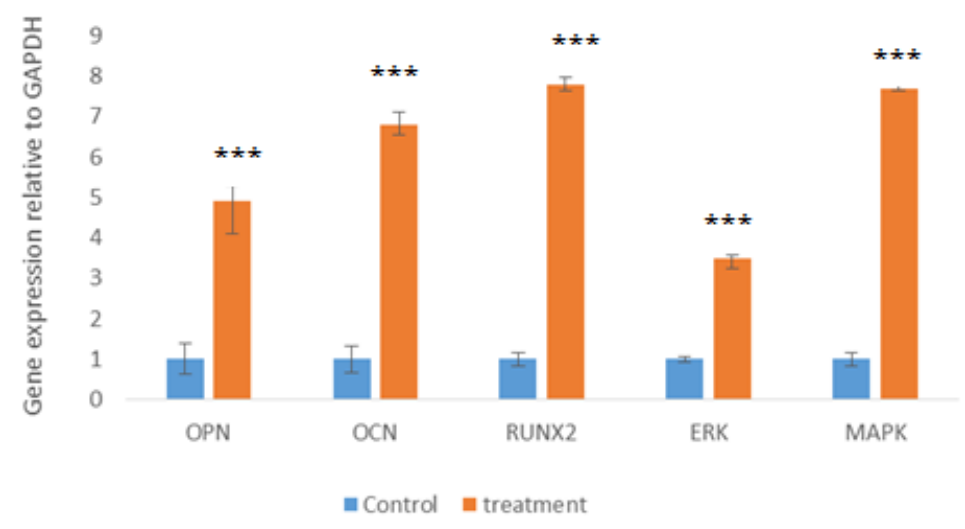

Figure 5. The effect of fisetin on genes expression in BMSCs: BMSCs were induced by $800 \mu \mathrm{g} / \mathrm{ml}$ treatment for

21 days. The mRNA expression in the cells was detected by Real TimePCR. OCN, OPN and RUNX2 are

osteoplastic markers. ERK and MAPK are genes that expression osteogenic pathway. (Mean $\pm \mathrm{S}$.E ، $* * * \mathrm{P}<$

$0.001)$

\section{Discussion}

Bone formation responds to a variety of stimuli, such as metabolic, physical, and endocrine genet. Bone tissue is a highly dynamic, it can be renewed and resorbed in different conditions (yang et al., 2014). Osteoporosis is a bone disease that has some symptoms, such as low bone density, decrease in bone strength and increased risk of bone fracture (Cheung et al., 2016). Osteoporosis can be treated by the inhibition of osteoclasts and stimulation of osteocytes activity (Gossiel et al., 2016). Estrogen therapy is the main choice for preventing osteoporosis-related abnormality, but the risks associated with estrogen treatment, causes limitations in using estrogen (Frisina et al., 2016). Phytoestrogens are plant secondary metabolic compounds, which are taken into consideration as a 
substitution in estrogen treatment (Moreira et al., 2014). It was known that phytoestrogens simulates estrogen effects, also, it was reported that they have beneficial effects on the bone health and bone regeneration (Lagari et al., 2013). Fisetin is a kind of phytoestrogen (Chen et al., 2016). BMSCs are multipotent stromal cells that can differentiate into mesenchymal cell lineages, such as; osteogenic, adipogenic, myogenic and chondrogenic lineages, many studies have been done on the use of mesenchymal stem cells for bone formation (Guihard et al., 2012). BMSCs can be stimulated to differentiate osteoblast by some osteogenic substrats (Fakhy et al., 2017). These conditions cause changes in morphology, proliferation, gene expression and molecular signaling of the cells (Fakhyet al., 2013). Therefore, the aim of current study was to investigate the osteogenic effects of fisetin on BMSCs. Using the appropriate dose for cell s' treatment is a very important issue, these doses should be chosen in a way that does not cause cell death and also have the maximum efficiency on cell differentiation (Piccinini et al., 2017). To determine the appropriate dose for the induction of differentiation, trypan blue assay was used; this assay detects the cell metabolic activity and viability (Piccinini et al., 2017). The results indicated that, the doses of fisetin that were less than $200 \mu \mathrm{g} / \mathrm{ml}$ had no significant effects on the proliferation of BMSCs. The doses between $200-800 \mu \mathrm{g} / \mathrm{ml}$ result in the increased proliferation and viability of cells. Hence, we used doses of fisetin between $200-800 \mu \mathrm{g} / \mathrm{ml}$ to induce differentiation on BMSCs. we investigated the effect of Alkalin phosphate enzyme activity on the detection of osteogenic. Alkaline phosphatase is an important component in hard tissue formation, highly expressed in mineralized tissue cells. This enzyme activity increased during days 10 to 14 of osteogenesis (Golub et al., 2007). Our result showed that fisetin with $800 \mu \mathrm{g} / \mathrm{ml}$ dose has the best effect on Alkalin phosphate activity in the tenth day. The mineralization of the bone matrix is the unique function of osteoblast, Calcium, is the most important and abundant mineral in bone, ARS has been used for decades to evaluate calciumrich deposits by cells in culture, detect and quantify calcium (Gregory et al., 2004). We found that fisetin by 800 $\mu \mathrm{g} / \mathrm{ml}$ dose causes the deposition of calcium for the bones' formatin, for the differentiation of osteoblasts expression of osteogenesis, some - related factors are necessary; we investigated the expression of Osteocalcin, Osteopontin, and RUNX2 genes. Osteocalcin is a late stage osteoblast specific protein, produced only by mature osteoblasts (Datta et al., 2013). Osteopontin is a protein that expression a variety of tissue types, including preosteoblasts, osteoblasts, and ostreocytes (28Casarin et al., 2014). Runx2 is a key organizer in developing and maturing osteoblast; it is a member of the runt homology domain transcription factor family, It is essential for osteoblast differentiation (Brudere et al., 2014). Our results demonstrated that fisetin at $800 \mu \mathrm{g} / \mathrm{ml}$ caused the expression of Osteocalcin, Osteopontin, and RUNX2 genes. These results are consistent with a prior report about phytoestrogen osteogenic effects, conducted by Shuping, who report that Icariin is a type of phytoestrogens which stimulates the osteogenic differentiation of bone marrow stromal cells (Shuping et al., 2016). Bitto showed that the Ginestein increases bone mineral content in osteoporotic ovariectomized rats; their results suggest that Geneistein can be an appropriate method for the treatment of postmenopausal osteoporosis (Bitto et al., 2008). Wang has reported that Notoginsenoside R1 ( a naval phytoestrogen) stimulates osteogenic function in primary osteoblasts via estrogen receptor signaling, Notoginsenside causes the increase in ALP activity and the osteogenic expression of such genes as RUNX2, ALP, OCN, COL1 in these cells (Wang et al., 2015). Genistein is a famous phytoestrogen that stimulates osteogenic differentiation and maturation of bone marrow stromal progenitor cells and osteoblasts, researcher showed that the treatment of bone marrow stromal cells with Ginestein causes ER, p38MAPK-Runx2 genes expression (Ming et al., 2013). Hsieh et al. (2010) treated primary osteoblastic cell with icariin phytoestrogen. Their result showed BMP-2, SMAD4, Cbfa1/Runx2, RANKL, and OPG gene expression and ALP activity in this cells (Hsieh et al., 2010). Other studies have investigated effect of Coumestrol on proliferation and osteoblastic differentiation in rat bone marrow stromal cells. Viability and ALP assays results showed that this phytoestrogen increases cellular activity, Coumestrol causes expression of OPG type 1 collagen, OCN, and estrogen receptor alpha genes (Wu et al., 2009).

In this study, the effect of fisetin on osteoblastic differentiation of BMSCs, and the role of the ERK1 and MAPK signaling pathways in fisetin mediated cell responses were examined. The results showed that fisetin activates ERK1 and MAPK pathways. researcher showed that various chemical and physical stimuli can lead to osteogenic differentiation through different signaling molecules (Yi et al., 2010).

MAPKs, are a family of serine/threonine kinase, where the signaling pathways in various cellular are involved in various events, such as, cell growth, survival, apoptosis, motility, metabolism, and differentiation (Wei et al., 2011). Suzuma showed that P38 MAPK pathways played critical roles in directing BMSCs commitment to the osteogenic lineage (Suzuma et al., 2002). Further, Li showed that p38 MAPK can positively regulate Osteogenic differentiation (Suzuma et al., 2002). The activation of ERK1 pathway leads to the transcription of such genes as Osteocalcin and Osteopointin, The activation of this pathway could be the reason for the differentiation of rat bone marrow-derived stem cells ( $\mathrm{Li}$ et al., 2002). Other studies showed that the activation of ERK1/2, a group of three 
MAPKs, is essential for embryo stem cells to escape self-renewal and commit to lineage differentiation. ERK1/2 is required for osteogenic mesenchymal (Jensen et al., 2010).

\section{Conclusion}

In conclusions, the results of current study showed that fisetin can increase the activity of ALP, calcium formation in the extracellular matrix and the expression of ostegenic genes OCN, OPN Runx2 in the treated cells. Fisetin induces differentiation in bone marrow stem cells to osteoblast via p38 MAPK and ERK1 pathways.

\section{Acknowledgment}

The authors have special thanks to the Science and Research Branch, Tehran Islamic Azad University, Tehran, Iran; Animal Development and Applied Biology Research Center of Mashhad Branch, Islamic Azad University, Mashhad, Iran for support of this work as PhD. Thesis.

\section{References}

Baglioni, S., Francalanci, M., Squecco, R., Lombardi, A., Cantini, G., Angeli, R., ... \& Bani, D. (2009). Characterization of human adult stem-cell populations isolated from visceral and subcutaneous adipose tissue. The FASEB Journal, 23(10), 3494-3505. https://doi.org/10.1016/j.jep.2015.11.007

Bitto, A., Burnett, B. P., Polito, F., Marini, H., Levy, R. M., Armbruster, M. A., ... \& Granese, R. (2008). Effects of genistein aglycone in osteoporotic, ovariectomized rats: a comparison with alendronate, raloxifene and oestradiol. British journal of pharmacology, 155(6), 896-905. https://doi.org/10.1038/bjp.2008.305

Bruderer, M., Richards, R. G., Alini, M., \& Stoddart, M. J. (2014). Role and regulation of RUNX2 in osteogenesis. Eur Cell Mater, 28(28), 269-86.

Casarin, R. C., Casati, M. Z., Pimentel, S. P., Cirano, F. R., Algayer, M., Pires, P. R., ... \& Ribeiro, F. V. (2014). Resveratrol improves bone repair by modulation of bone morphogenetic proteins and osteopontin gene expression in rats. International journal of oral and maxillofacial surgery, 43(7), 900-906. https://doi.org/10.1016/j.ijom.2014.01.009

Chen, X., Uzuner, U., Li, M., Shi, W., Yuan, J. S., \& Dai, S. Y. (2016). Phytoestrogens and Mycoestrogens Induce Signature Structure Dynamics Changes on Estrogen Receptor $\alpha$. International journal of environmental research and public health, 13(9), 869. https://doi.org/10.3390/ijerph13090869

Cheung, A., Papaioannou, M., \& Morin, A., S. (2016). Osteoporosis Canada Scientific Advisory Council. Postmenopausal Osteoporosis. The New England Journal of Medicine, 374(21), 2065-2097. https://doi.org/10. 1056/NEJMc1602599

Chlebowski, R. T., Rohan, T. E., Manson, J. E., Aragaki, A. K., Kaunitz, A., Stefanick, M. L., ... \& AdamsCampbell, L. L. (2015). Breast cancer after use of estrogen plus progestin and estrogen alone: analyses of data from 2 women's health initiative randomized clinical trials. JAMA oncology, 1(3), 296-305. https://doi.org/10.1001/jamaoncol.2015.0494

Datta, P., Ghosh, P., Ghosh, K., Maity, P., Samanta, S. K., Ghosh, S. K., ... \& Dhara, S. (2013). In Vitro ALP and Osteocalcin Gene Expression Analysis and In VivoBiocompatibility of N-Methylene Phosphonic Chitosan Nanofibers for Bone Regeneration. Journal of biomedical nanotechnology, 9(5), 870-879.

Fakhry, M., Hamade, E., Badran, B., Buchet, R., \& Magne, D. (2013). Molecular mechanisms of mesenchymal stem cell differentiation towards osteoblasts. World journal of stem cells, 5(4), 136. https://doi.org/10.4252/ wjsc.v5.i4.136

Frisina, R. D., \& Frisina, D. R. (2016). Hormone Replacement Therapy and Its Effects on Human Hearing. In Hearing and Hormones (pp. 191-209). Springer International Publishing.

Gambini, J., Inglés, M., Olaso, G., Lopez-Grueso, R., Bonet-Costa, V., Gimeno-Mallench, L., ... \& Borras, C. (2015). Properties of resveratrol: in vitro and in vivo studies about metabolism, bioavailability, and biological effects in animal models and humans. Oxidative medicine and cellular longevity, 2015. https://doi.org/10.1155/2015/837042

Golub, E. E., \& Boesze-Battaglia, K. (2007). The role of alkaline phosphatase in mineralization. Current Opinion in Orthopaedics, 18(5), 444-448. https://doi.org/10.1097/BCO.0b013e3282630851

Gossiel, F., Hoyle, C., McCloskey, E. V., Naylor, K. E., Walsh, J., Peel, N., \& Eastell, R. (2016). The effect of bisphosphonate treatment on osteoclast precursor cells in postmenopausal osteoporosis: The TRIO study. Bone, 92, 94-99. https://doi.org/10.1016/j.bone.2016.08.010 
Gregory, C. A., Gunn, W. G., Peister, A., \& Prockop, D. J. (2004). An Alizarin red-based assay of mineralization by adherent cells in culture: comparison with cetylpyridinium chloride extraction. Analytical biochemistry, 329(1), 77-84. https://doi.org/10.1016/j.ab.2004.02.002

Guihard, P., Danger, Y., Brounais, B., David, E., Brion, R., Delecrin, J., ... \& Gascan, H. (2012). Induction of osteogenesis in mesenchymal stem cells by activated monocytes/macrophages depends on oncostatin $\mathrm{M}$ signaling. Stem cells, 30(4), 762-772. https://doi.org/10.1002/stem.1040.

Hsieh, T. P., Sheu, S. Y., Sun, J. S., Chen, M. H., \& Liu, M. H. (2010). Icariin isolated from Epimedium pubescens regulates osteoblasts anabolism through BMP-2, SMAD4, and Cbfa1 expression. Phytomedicine, 17(6), 414423. https://doi.org/10.1016/j.phymed.2009.08.007

Jensen, E. D., Gopalakrishnan, R., \& Westendorf, J. J. (2010). Regulation of gene expression in osteoblasts. Biofactors, 36(1), 25-32. https://doi.org/10.1002/biof.72

Jia, M., Dahlman-Wright, K., \& Gustafsson, J. Å. (2015). Estrogen receptor alpha and beta in health and disease. Best practice \& research Clinical endocrinology \& metabolism, 29(4), 557-568. https://doi.org/10.1016/j.beem.2015.04.008

Kulpa, J., Chinnappareddy, N., \& Pyle, W. G. (2012). Rapid changes in cardiac myofilament function following the acute activation of estrogen receptor-alpha. PLOS ONE, 7(7), 1-11. https://doi.org/10.1371/journal. pone. 0041076

Lagari, V. S., \& Levis, S. (2013). Phytoestrogens in the prevention of postmenopausal bone loss. Journal of Clinical Densitometry, 16(4), 445-449. https://doi.org/10.1016/j.jocd.2013.08.011

Lall, R. K., Adhami, V. M., \& Mukhtar, H. (2016). Dietary flavonoid fisetin for cancer prevention and treatment. Molecular nutrition \& food research, 60(6), 1396-1405. https://doi.org/10.1002/mnfr.201600025

Li, X., Udagawa, N., Itoh, K., Suda, K., Murase, Y., Nishihara, T., ... \& Takahashi, N. (2002). p38 MAPKmediated signals are required for inducing osteoclast differentiation but not for osteoclast function. Endocrinology, 143(8), 3105-3113. https://doi.org/10.1210/endo.143.8.8954

Michelin, R. M., Al-Nakkash, L., Broderick, T. L., \& Plochocki, J. H. (2016). Genistein treatment increases bone mass in obese, hyperglycemic mice. Diabetes, metabolic syndrome and obesity: targets and therapy, 9, 63. https://doi.org/10.2147/DMSO.S97600

Ming, L. G., Chen, K. M., \& Xian, C. J. (2013). Functions and action mechanisms of flavonoids genistein and icariin in regulating bone remodeling. Journal of cellular physiology, 228(3), 513-521. https://doi.org/10. $1002 /$ jcp. 24158

Moreira, A. C., Silva, A. M., Santos, M. S., \& Sardão, V. A. (2014). Phytoestrogens as alternative hormone replacement therapy in menopause: What is real, what is unknown. The Journal of steroid biochemistry and molecular biology, 143, 61-71. https://doi.org/10.1016/j.jsbmb.2014.01.016

Nanashima, N., Horie, K., Tomisawa, T., Chiba, M., Nakano, M., Fujita, T., ... \& Watanabe, J. (2015). Phytoestrogenic activity of blackcurrant (Ribes nigrum) anthocyanins is mediated through estrogen receptor alpha. Molecular nutrition \& food research, 59(12), 2419-2431. https://doi.org/10.1002/mnfr.201500479

Niada, S., Giannasi, C., Ferreira, L. M. J., Milani, A., Arrigoni, E., \& Brini, A. T. (2016). 17ß-estradiol differently affects osteogenic differentiation of mesenchymal stem/stromal cells from adipose tissue and bone marrow. Differentiation, 92(5), 291-297. https://doi.org/10.1016/j.diff

Nongmaithem, R. S., Pertin, M., Chiru, C., \& Jotin, Y. (2016). Bone mineral density profile among postmenopausal women in Manipur: a hospital-based study. International journal of rheumatic diseases. https://doi.org/10.1111/1756-185X.12825

Pal, H. C., Diamond, A. C., Strickland, L. R., Kappes, J. C., Katiyar, S. K., Elmets, C. A., ... \& Afaq, F. (2016). Fisetin, a dietary flavonoid, augments the anti-invasive and anti-metastatic potential of sorafenib in melanoma. Oncotarget, 7(2), 1227. https://doi.org/10.18632/oncotarget.6237

Piccinini, F., Tesei, A., Arienti, C., \& Bevilacqua, A. (2017). Cell Counting and Viability Assessment of 2D and 3D Cell Cultures: Expected Reliability of the Trypan Blue Assay. Biological procedures online, 19(1), 8. https://doi.org/10.1186/s12575-017-0056-3

Schilling, T., Ebert, R., Raaijmakers, N., Schütze, N., \& Jakob, F. (2014). Effects of phytoestrogens and other plant-derived compounds on mesenchymal stem cells, bone maintenance and regeneration. The Journal of steroid biochemistry and molecular biology, 139, 252-261. https://doi.org/10.1016/j.jsbmb.2012.12.006 
Sealy-Jefferson, S., Cote, M. L., Beebe-Dimmer, J., Chlebowski, R., Rexrode, K., \& Simon, M. (2016). An evaluation of the post-stroke cancer risk among post-menopausal women: The Women's Health Initiative. Cancer Research, 76(14), p.1766. https://doi.org/10.1158/1538-7445

Shuping, F., Li, Y., Hao, H., \& Ronghua, Z. (2016). Wnt/ $\beta$-catenin signaling is involved in the Icariin induced proliferation of bone marrow mesenchymal stem cells. Journal of Traditional Chinese Medicine, 36(3), 360368. https://doi.org/10.1016/S0254-6272(16)30050-4

Suzuma, I., Suzuma, K., Ueki, K., Hata, Y., Feener, E. P., King, G. L., \& Aiello, L. P. (2002). Stretch-induced retinal vascular endothelial growth factor expression is mediated by phosphatidylinositol 3-kinase and protein kinase C (PKC)- $\zeta$ but not by stretch-induced ERK1/2, Akt, Ras, or classical/novel PKC pathways. Journal of Biological Chemistry, 277(2), 1047-1057. https://doi.org/10.1074/jbc.M105336200

Wang, T., Wan, D., Shao, L., Dai, J., \& Jiang, C. (2015). Notoginsenoside R1 stimulates osteogenic function in primary osteoblasts via estrogen receptor signaling. Biochemical and biophysical research communications, 466(2), 232-239. https://doi.org/10.1016/j.bbrc.2015.09.014

Wang, Y. X., Li, M., Zhang, H. Q., Tang, M. X., Guo, C. F., Deng, A., ... \& Xiao, L. G. (2016). Opposite Function of ER $\alpha$ and ER $\beta$ in Controlling 17 -Estradiol-mediated Osteogenesis in Osteoblasts. Archives of medical research, 47(4), 255-261. https://doi.org/10.1016/j.arcmed.2016.07.002

Wei, Y. J., Tsai, K. S., Lin, L. C., Lee, Y. T., Chi, C. W., Chang, M. C., ... \& Hung, S. C. (2011). Catechin stimulates osteogenesis by enhancing PP2A activity in human mesenchymal stem cells. Osteoporosis international, 22(5), 1469-1479. https://doi.org/10.1007/s00198-010-1352-9

Wu, X. T., Wang, B., \& Wei, J. N. (2009). Coumestrol promotes proliferation and osteoblastic differentiation in rat bone marrow stromal cells. Journal of Biomedical Materials Research Part B: Applied Biomaterials, 90(2), 621-628. https://doi.org/10.1002/jbm.b.31326

Yang, L., Tsang, K. Y., Tang, H. C., Chan, D., \& Cheah, K. S. (2014). Hypertrophic chondrocytes can become osteoblasts and osteocytes in endochondral bone formation. Proceedings of the National Academy of Sciences, 111(33), 12097-12102. https://doi.org/10.1073/pnas.1302703111

Yi, C., Liu, D., Fong, C. C., Zhang, J., \& Yang, M. (2010). Gold nanoparticles promote osteogenic differentiation of mesenchymal stem cells through p38 MAPK pathway. Acs Nano, 4(11), 6439-6448. https://doi.org/10.1021/nn101373r

\section{Copyrights}

Copyright for this article is retained by the author(s), with first publication rights granted to the journal.

This is an open-access article distributed under the terms and conditions of the Creative Commons Attribution license (http://creativecommons.org/licenses/by/4.0/). 